\title{
KANDUNGAN LOGAM BERAT PB PADA SEDIMEN DAN KERANG (POLYMESODA EROSA) DI PERAIRAN KOEONO, KECAMATAN PALANGGA SELATAN, KABUPATEN KONAWE SELATAN
}

\section{Pb Heavy Metal Content in Sediment and Clams (Polymesoda erosa) in Koeono Waters of Palangga Selatan District, South Konawe Regency}

\author{
Reni Ulfa Mariani ${ }^{1 *}$, Emiyarti $^{2}$, La Ode Muhammad Yasir Haya ${ }^{2}$ \\ 1,2 Program Studi Ilmu Kelautan, Fakultas Perikanan dan Ilmu Kelautan, Universitas Halu Oleo. \\ Jl. H.E.A Mokodompit Kampus Hijau Bumi Tridharma Anduonohu Kendari 93232. \\ *E-mail: reniulfa059@gmail.com
}

\begin{abstract}
Abstrak
Perairan Koeono merupakan pusat aktifitas pertambangan jenis ore nickel. Kondisi perairan tersebut diduga telah tercemar logam berat diantaranya jenis logam berat Timbal $(\mathrm{Pb})$, namun informasi tentang konsentrasi bahan pencemar berbahaya (logam berat $\mathrm{Pb}$ ) di lokasi penelitian belum tersedia. Tujuan penelitian ini adalah untuk mengetahui kandungan logam berat $\mathrm{Pb}$ pada sedimen dan Bivalvia jenis kerang (Polymesoda erosa) di Perairan Koeono. Metode penelitian menggunakan metode purposive sampling. Sampel diambil dengan dua kali pengulangan. Analisa logam berat $\mathrm{Pb}$ menggunakan metode Atomic Absorbtion Spectrophotometry (AAS). Berdasarkan hasil penelitian, konsentrasi logam berat Timbal $(\mathrm{Pb})$ pada sedimen berada pada kisaran $0.145-0.345 \mathrm{mg} / \mathrm{l}$ dan kerang jenis polymesoda erosa pada kisaran 1.14-2.65 mg/l. Berdasarkan standar baku mutu oleh Kepmen LH No 51 Tahun 2004 dan BPOM dinyatakan kandungan timbal pada sedimen dan kerang (Polymesoda erosa) sudah melewati ambang batas baku mutu dan kerang tidak layak dikonsumsi.
\end{abstract}

Kata kunci: Kerang; Sedimen; logam berat Pb; Perairan Koeono

\begin{abstract}
Koeono Waters is the center of mining activity for nickel ore types. The condition of the waters is having been contaminated by heavy metals, including $\mathrm{Pb}$ heavy metal, but information about the concentration of hazardous pollutants $(\mathrm{Pb}$ heavy metals) at the study site was not yet available. The purpose of this study was to determine the $\mathrm{Pb}$ heavy metal content in sediments and Bivalvia types of Clams (Polymesoda erosa) in Koeono Waters. The research method was used in a purposive sampling method, and samples were taken with two repetitions. Pb heavy metal analysis was used the "Atomic Absorption Spectrophotometry (AAS)" method. Based on the results, the concentration of Pb heavy metals in sediments is in the range of 0.145-0.345 mg/l, and the clam of Polymesoda erosa between 1.14 and $2.65 \mathrm{mg} / \mathrm{l}$. Based on the quality standard by the Minister of Environment Decree No. 51 of 2004 and National Agency of Drug and Food Control (BPOM), it is stated that the lead content in sediments and Clams of Polymesoda erosa has passed the quality standard threshold and the clams are not recommended for consumption.
\end{abstract}

Keywords: Clams; Sediment; $\mathrm{Pb}$ heavy metals; Koeono Waters

\section{Pendahuluan}

Timbal $(\mathrm{Pb})$ merupakan salah satu logam berat yang sangat berbahaya bagi kesehatan manusia serta merupakan unsur logam berat yang tidak dapat terurai oleh proses alam (Zang et al, 2007). Logam $\mathrm{Pb}$ terdapat di perairan bersumber baik secara alamiah maupun berasal dampak dari aktivitas manusia. Logam ini masuk ke perairan melalui pengkristalan $\mathrm{Pb}$ di udara dengan bantuan air hujan. Selain itu, proses korofikasi dari batuan mineral juga merupakan salah satu jalur masuknya sumber $\mathrm{Pb}$ ke perairan (Palar, 1994).

Penelitian yang dilakukan oleh Rochyatun dan Rozak (2007) di Perairan Teluk Jakarta menunjukkan bahwa konsentrasi logam berat pada sedimen sedikit lebih tinggi jika dibandingkan dengan konsentrasi logam berat pada air laut sehingga sedimen menjadi indikator yang penting untuk melihat pencemaran perairan yang diakibatkan logam berat. Keberadaan logam berat di perairan dalam waktu yang lama akan turun dan mengendap ke dasar perairan membentuk sedimen. Sedimen atau substrat di dasar perairan merupakan habitat bagi berbagai jenis kerang-kerangan salahsatunya kerang Kalandue (Polymesoda erosa).

Kerang kalandue (Polymesoda erosa) merupakan salah satu jenis biota laut yang merupakan filter feeder atau menyaring makanan yang bertingkah laku sebagai vacum 
cleaner. Keberadaan kerang Kalandue di perairan dapat menjadi salah satu indikator biologi (bio-indicator) untuk mendeteksi adanya pencemaran perairan yang bersumber dari logam berat disebabkan sifat alamiahnya yang menetap di dasar perairan. Salah satu lokasi yang berpotensi terjadinya pencemaran logam berat di lingkungan perairan adalah Perairan Desa Koeono, Konawe Selatan.

Desa Koeono Kabupaten Konawe Selatan merupakan daerah aktifitas pertambangan yaitu jenis ore nikel. Di perairan ini, sumber $\mathrm{Pb}$ diduga berasal dari pembuangan limbah oleh kapal angkut ore nikel (transportasi), material yang terbawa oleh hujan ke laut, dan tumpahan BBM (oli, solar, bensin) dari kapal motor nelayan di sekitarnya. Pada sisi lainnya, perairan Koeono merupakan daerah penangkapan ikan/biota laut oleh masyarakat pesisir dan nelayan sebagai sumber mata pencaharian.

Tujuan penelitian ini adalah untuk mengetahui kandungan logam berat $\mathrm{Pb}$ pada sedimen dan Bivalvia jenis kerang (Polymesoda erosa) di Perairan Koeono Manfaat yang ingin dicapai dari penelitian ini adalah sebagai bahan masukan bagi masyarakat sekitar Perairan Desa Koeono tentang bahaya logam berat $(\mathrm{Pb})$ yang masuk ke dalam tubuh melalui makanan yang di konsumsi dari Perairan Koeono agar dapat dilakukan pengelolaan untuk mencegah terjadinya penurunan kualitas perairan.

\section{Bahan dan Metode}

Penelitian ini dilaksanakan pada bulan April - Desember 2019, meliputi; studi literature, penyusunan proposal penelitian, pengambilan data lapangan, analisa data dan laboratorium, penyusunan laporan akhir, dan seminar hasil, serta ujian.. Lokasi pengambilan sampel $\mathrm{Pb}$ sedimen dan kerang (Polymesoda erosa) pada penelitian ini dilakukan di Perairan Koeono Kabupaten Konawe Selatan. Untuk menganalisa sampel sedimen dan kerang (Polymesoda erosa) dilakukan di Balai Besar Laboratorium Kesehatan Makassar, Sulawesi Selatan.

Penentuan stasiun dilakukan secara purposive sampling, yaitu stasiun penelitian ditentukan berdasarkan lokasi atau daerah yang terkena dampak akibat aktivitas kegiatan pertambangan dimana penentuan stasiun pengambilan sampel dilakukan pada banyaknya aktivitas yang dapat menimbulkan pencemaran di Perairan Desa Koeono Kabupaten Konawe Selatan yang dibagi ke dalam 2 stasiun pengamatan. Stasiun I yang merupakan stasiun yang berada dekat aliran sungai yang menuju ke laut ( $4^{\circ} 27^{\prime} 28.44^{\prime}$ 'LS - $\left.122^{\circ} 22^{\prime} 32.82^{\prime \prime} B T\right)$. Stasiun II berada di ekosistem mangrove ( $4^{\circ} 28^{\prime} 0.53^{\prime \prime} \mathrm{LS}-122^{\circ} 21^{\prime}$ ' 15.40”BT).

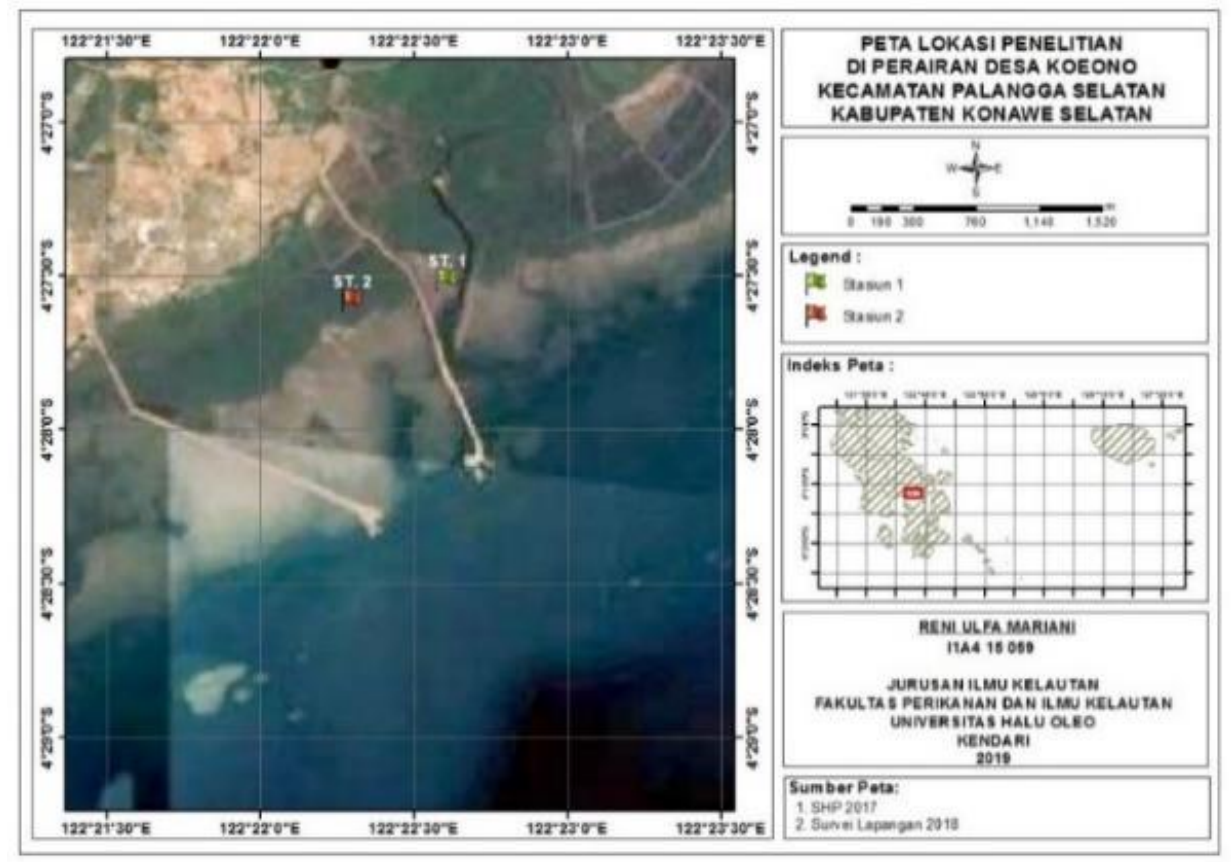

Gambar 1. Lokasi Penelitian Pengambilan Sampel 
Tabel 1. Parameter alat dan bahan beserta kegunaannya.

\begin{tabular}{|c|c|c|c|c|}
\hline No & & Alat dan bahan & Satuan & Kegunaan \\
\hline \multirow[t]{13}{*}{1} & Alat & & & \\
\hline & - & Handrafraktometer & $\mathrm{ppt}$ & Mengukur salinitas \\
\hline & - & Thermometer & ${ }^{\circ} \mathrm{C}$ & Mengukur suhu \\
\hline & - & Pipet volum & $\%$ & Melihat tekstur sedimen \\
\hline & - & Soil tester & - & Mengukur $\mathrm{pH}$ sedimen \\
\hline & - & $\mathrm{pH}$ indikator & - & Mengukur $\mathrm{pH}$ air \\
\hline & - & AAS & ppm & Melihat kandungan Timbal $(\mathrm{Pb})$ \\
\hline & - & Pipa paralon & - & Mengambil fraksi sedimen \\
\hline & - & Pisau & - & Mengambil daging kerang \\
\hline & - & Cool box & - & Menyimpan sampel \\
\hline & - & Kamera & - & Mengambil dokumentasi \\
\hline & - & Plastik sampel & - & Menyimpan sampel \\
\hline & - & Menyimpan sampel & - & Memberi tanda pada sampel \\
\hline \multirow[t]{6}{*}{2} & Bahan & & & \\
\hline & - & Kerang & - & Sampel penelitian \\
\hline & - & Aquades & $\mathrm{ml}$ & Mensterilkan alat \\
\hline & - & Suprapur perchloric acid & $\mathrm{ml}$ & Pengikat logam kuat \\
\hline & - & Larutan $\mathrm{NHO}_{3}$ & $\mathrm{ml}$ & Pengikat logam \\
\hline & - & Larutan $\mathrm{H}_{2} \mathrm{SO}_{4}$ & $\mathrm{ml}$ & Pengencer sedimen \\
\hline
\end{tabular}

Prosedur penelitian meliputi survey pendahuluan, penentuan stasiun penelitian dan pengambilan sampel Sedimen dan Kerang (Polymesoda erosa). Kegiatan survei pendahuluan atau observasi awal dilakukan untuk mengetahui gambaran umum lokasi penelitian terkait logam berat Timbal $(\mathrm{Pb})$ di Perairan Koeono Kabupaten Konawe Selatan sehingga lebih mudah untuk menentukan stasiun pengamatan

Metode penelitian ini menggunakan metode AAS (Anatomic Absorbtion Spectrophotometry).

\section{Hasil dan Pembahasan}

Parameter kualitas perairan yang diukur selama penelitian terdiri suhu, $\mathrm{pH}$, dan salinitas. Suhu merupakan salah satu faktor yang sangat penting dalam mengatur proses kehidupan dan penyebaran organisme di perairan. Laju metabolisme, distribusi dan kelimpahan beberapa jenis dipengaruhi oleh suhu. Kebanyakan organisme laut telah banyak mengalami adaptasi untuk hidup dan berkembang biak pada kisaran suhu $0-40{ }^{\circ} \mathrm{C}$ (Putra, 2016). Suhu terendah di stasiun pengamatan terdapat di Stasiun I dengan nilai $28^{\circ} \mathrm{C}-$ $29^{\circ} \mathrm{C}$ dan suhu tertinggi terdapat di Stasiun II dengan nilai $29^{\circ} \mathrm{C}-30^{\circ} \mathrm{C}$.
Nilai pengukuran suhu perairan di Stasiun I dan II relatif sama dengan kisaran $28^{\circ} \mathrm{C}-30^{\circ} \mathrm{C}$. Hal ini sesuai dengan pernyataan Effendi (2003), Bahwa suhu suatu badan air dipengaruhi oleh musim, lintang (latitude), ketinggian dari permukaan laut (altitude), waktu dalam satu hari, siklus udara, penutupan awan, dan aliran serta kedalaman badan air, kenaikan suhu tidak hanyan meningkatkat metabolisme biota perairan, namun juga dapat meningkatkan toksititas logam berat di perairan.

Kisaran suhu pada lokasi penelitian masih berada pada kisaran alami/normal sehingga dapat mendukung kehidupan biota laut, termasuk kerang. Hal ini sesuai dengan standar baku mutu Kepmen LH No. 51 tahun 2004 bahwa kisaran suhu untuk biota laut berkisar $28-30^{\circ} \mathrm{C}$.

Nilai $\mathrm{pH}$ perairan memiliki hubungan yang erat dengan sifat kelarutan logam berat, dimana kenaikan $\mathrm{pH}$ dapat menyebabkan penurunan logam berat. Kenaikan $\mathrm{pH}$ di perairan akan diikuti dengan penurunan kelarutan logam berat, karena kenaikan $\mathrm{pH}$ mengubah kestabilan dari bentuk karbonat menjadi hidroksida yang membentuk ikatan dengan partikel pada badan air, sehingga akan mengendap membentuk lumpur (Palar 2008). Nilai pH di Perairan Koeono berkisar antara 7. 
Tabel 2. Parameter Kualitas Perairan

\begin{tabular}{cccc}
\hline \multirow{2}{*}{ Stasiun } & \multicolumn{3}{c}{ Parameter } \\
\cline { 2 - 4 } & $\mathbf{p H}$ & $\begin{array}{c}\text { Salinitas } \\
(\mathbf{p p t})\end{array}$ & $\begin{array}{c}\text { Suhu } \\
\left({ }^{\circ} \mathbf{C}\right)\end{array}$ \\
\hline I & 7 & 27 & 28 \\
& 7 & 27 & 29 \\
II & 7 & 29 & 29 \\
& 7 & 28 & 30 \\
\hline
\end{tabular}

Nilai $\mathrm{pH}$ yang didapat dari masing-masing stasiun menunjukkan bahwa kondisi Perairan Koeono masih tergolong baik bagi biota laut dan kehidupan organisme yang terdapat di lokasi tersebut. Hal tersebut ditinjau berdasarkan Keputusan Menteri Negara Lingkungan Hidup No.51 Tahun 2004 mengenai baku mutu air laut yang berkisar pada $\mathrm{pH} 7-8$.

Stabilitas $\mathrm{pH}$ di Perairan Koeono pada kisaran 7 menunjukkan tingkat kestabilan ikatan ion karbonat menjadi hidroksida dalam pembentukan ikatan partikel air dan pelepasan ion. Menurut Antelo et al., (2014) bahwa salah satu faktor yang dapat meningkatkan $\mathrm{pH}$ di air diakibatkan oleh lepasnya ion-ion positif (kation). Salinitas merupakan ukuran bagi jumlah berbagai zat padat yang larut dalam air. Di perairan samudera salinitas dapat mencapai 34-35 $\%$ sedangkan pada daerah dekat pantai dapat terjadi pengenceran karena adanya aliran sungai. Secara umum salinitas permukaan air laut di Indonesia berkisar 24-34 \% (Armis, 2017).

Salinitas juga dapat mempengaruhi keberadaan logam berat di perairan, bila terjadi penurunan salinitas karena adanya proses desalinasi maka akan menyebabkan peningkatan daya toksik logam berat dan tingkat bioakumulasi logam berat semakin besar (Erlangga, 2007). Berdasarkan dampak yang ditimbulkan dari pencemaran oleh logam berat tersebut terutama di badan perairan, maka sangat diperlukan kisaran konsentrasi atau nilai ambang batas dari konsentrasi logam berat yang direkomendasikan untuk masuk dan berada di lingkungan perairan.

Berdasarkan hasil pengukuran dengan kisaran salinitas tertinggi pada Stasiun II yaitu kisaran $28 \mathrm{ppt}-29 \mathrm{ppt}$, hal ini di duga karena stasiun ini terletak jauh dari muara sungai sehingga masukkan air laut lebih besar dibandingkan air tawar. Sebaliknya, Kisaran nilai salinitas terendah pada Stasiun I yaitu 27 ppt - 27 ppt karena Stasiun ini berada di sekitar muara sungai. Deri (2012) menambahkan nilai salinitas pada perairan pesisir sangat dipengaruhi oleh masukkan air tawar dari sungai.

Nilai salinitas perairan laut dapat mempengaruhi faktor konsentrasi logam berat yang mencemari lingkungan laut, dimana penurunan salinatas pada perairan dapat menyebakan tingkat bioakumulasi logam berat pada organisme semakin meningkat (Ahmed, 2010). Dalam hal ini, nilai salinitas pada tiap stasiun masih bisa ditolerir oleh kerang kalandue, sesuai peryataan Bahtiar (2005) nilai saliniitas yang sesuai dengan habitat kerang sebesar $25 \mathrm{ppt}-30 \mathrm{ppt}$.

Nilai $\mathrm{pH}$ tertinggi terdapat pada Stasiun I yaitu berkisar $6.9-6.7$ dan nilai terendah Nilai $\mathrm{pH}$ tertinggi bersifat asam terdapat pada Stasiun I yaitu berkisar 6.9 - 6.7 dan nilai terendah terdapat pada Stasiun II yaitu 6.8 . Secara umum nilai $\mathrm{pH}$ di setiap stasiun tidak jauh berbeda yang menunjukan bahwa perairan tersebut berada dalam kondisi normal. Hal ini dipengaruhi oleh tingginya sedimentasi yang banyak lumpur yang secara umum diketahui memiliki kandungan bahan organik. Odum (1996), menyatakan bahwa $\mathrm{pH}$ sedimen sangat erat kaitannya dengan bahan organik substrat, tipe substrat dan kandungan oksigen. Pada kolom air yang mepunyai derajat keasaman $\mathrm{pH}$ mendekati normal (7-8) kelarutan dari bentuk persenyawaan logam ini cenderung stabil (Palar, 2004). Kenaikan $\mathrm{pH}$ di perairan akan diikuti dengan kelarutan logam berat sehingga logam berat cukup mengendap.

Sedimen di Perairan Koeono terdiri dari berbagai tipe substrat yang berbeda penentuan jenis dan komposisi sedimen di lakukan dengan mengidentifikasi fraksi-fraksi yang pembentuknya yakni pasir, liat dan debu (Tabel 3). 
Tabel 3. Parameter Kualitas Sedimen.

\begin{tabular}{|c|c|c|c|c|c|}
\hline \multirow{2}{*}{ Stasiun } & \multicolumn{3}{|c|}{ Fraksi Sedimen } & \multirow{2}{*}{ Kelas } & \multirow{2}{*}{$\begin{array}{c}\text { pH } \\
\text { Sedimen }\end{array}$} \\
\hline & $\operatorname{Debu}(\%)$ & Liat $(\%)$ & Pasir(\%) & & \\
\hline I & 19.43 & 9.533 & 71.03 & Pasir Berlempung & $\begin{array}{l}6.9 \\
6.7\end{array}$ \\
\hline II & 10.82 & 45.66 & 43.50 & Liat & $\begin{array}{l}6.8 \\
6.8\end{array}$ \\
\hline
\end{tabular}

Keterangan :*Tekstur Sedimen Menggunakan Metode Titrasi Pipet Volum.

Tabel 4. Nilai Logam Berat Pb Pada Sedimen dan Kerang

\begin{tabular}{cccc}
\hline Stasiun & $\begin{array}{c}\text { Pb pada Sedimen } \\
(\mathbf{m g} / \mathbf{l})\end{array}$ & $\begin{array}{c}\text { Pb pada Kerang } \\
(\mathbf{m g} / \mathbf{k g})\end{array}$ & Lokasi Sampel \\
\hline I & 0.205 & 1.48 & Non Mangrove \\
& 0.345 & 2.26 & Non Mangrove \\
II & 0.226 & 1.14 & Mangrove \\
& 0.145 & 2.65 & Mangrove \\
\hline
\end{tabular}

Berdasarkan hasil pengukuran kadar logam berat Timbal $(\mathrm{Pb})$ pada sedimen di kawasan Perairan Koeono menunjukkan bahwa kadar logama berat $\mathrm{Pb}$ pada setiap stasiun pengamatan cenderung berbeda antara satu stasiun dengan lainnya. Hasil pengukuran menunjukan bahwa kisaran tertinggi berada pada Stasiun I yaitu $0.205-0.345 \mathrm{mg} / \mathrm{l}$ dan kandungan logam berat timbal terendah pada Stasiun II dengan kisaran yaitu $0.226-0.145$ $\mathrm{mg} / \mathrm{l}$ (Tabel 5). Tingginya kadar logam berat $\mathrm{Pb}$ pada Stasiun I diduga karena pengambilan sampel sedimen dilakukan pada musim penghujan. Konsentrasi $\mathrm{Pb}$ pada sedimen umumnya rendah pada musim kemarau dan tinggi pada musim penghujan. Penyebab tingginya konsentrasi $\mathrm{Pb}$ dalam sedimen pada musim penghujan dapat disebabkan oleh tingginya laju erosi pada permukaan tanah yang terbawa ke dalam badan sungai. Partikel organik dan anorganik dari hasil erosi tanah di daratan ini mengandung $\mathrm{Pb}$ dari limbah domestik, sisa pembakaran limbah domestik (misalnya baterai, kertas mengkilap, kaleng) dan dari sedimentasi partikulat $\mathrm{Pb}$ sisa hasil pembakaran mesin berbahan bakar bensin. Hal ini sesuai dengan laporan penelitian Fitriani. et.al (2013), menyatakan bahwa Konsentrasi $\mathrm{Pb}$ pada sedimen di Perairan Biringkassi terlihat berada di urutan ketiga jika dibandingkan dengan di beberapa perairan lain di Indonesia. Konsentrasi $\mathrm{Pb}$ di Perairan Biringkassi ini relatif tinggi, bahkan lebih tinggi dari Teluk Jakarta. Konsentrasi $\mathrm{Pb}$ di Perairan Biringkassi banyak disebabkan oleh adanya aktivitas bongkar-muat batubara di pelabuhan Biringkassi. Relatif tingginya konsentrasi $\mathrm{Pb}$ pada sedimen dari perairan Biringkassi dapat juga disebabkan oleh pengambilan sampel sedimen yang dilakukan pada musim penghujan.

Menurut Amin (2002), bahwa tipe sedimen dapat mempengaruhi kandungan logam berat dalam sedimen, dengan kategori kandungan logam berat dalam lumpur > lumpur berpasir $>$ berpasir. Pendapat tersebut juga berbanding lurus dengan pendapat Erlangga (2007), bahwa konsentrasi logam berat tertinggi terdapat dalam sedimen yang berupa lumpur, tanah liat, pasir berlumpur dan campuran dari ketiganya dibandingkan dengan sedimen yang berupa pasir. Hal ini disebabkan karena ukuran partikel sedimen yang halus memiliki luas permukaan yang besar sehingga mampu mengikat logam berat $\mathrm{Pb}$ lebih banyak dari pada ukuran partikel sedimen yang lebih besar (Sahara, 2009).

Pengukuran kadar logam berat $\mathrm{Pb}$ yang terendah pada Stasiun II di kawasan mangrove. Namun, tingkat cemaran sedimen di kawasan ini dinilai lebih kecil dari Stasiun I. Hal ini dikarenakan kandungan logam berat $\mathrm{Pb}$ pada kawasan ini telah banyak terminimalisir oleh mangrove mengingat mangrove yang bersifat sebagai penyerap logam di daerah tersebut terdapat banyak 
jenis, Selain itu di lokasi ini juga terdapat hutan mangrove yang dapat menyerap masuknya logam berat mangrove yang ditemukan pada kawasan Perairan Koeono tergolong dalam spesies Rhizophora. Menurut Hamzah dan Setiawan (2010), akar Rhizophora memiliki kemampuan sedang dalam menyerap logam $\mathrm{Pb}$ dibandingkan dengan Avicennia dan Soneratia. Menurut Heriyanto (2011), spesies Rhizophora memiliki kemampuan menyerap logam $\mathrm{Pb}$ hingga 7,933 ppm. Hal ini sesuai dengan pernyataan Heru (2013), Tumbuhan mangrove mempunyai fungsi ekologi yaitu dapat menyerap, mengangkut dan menimbun materi yang bersifat toksik yang berasal dari sekitar lingkungan tempat tumbuhnya salah satunya adalah logam berat. Oleh karena itu kandungan logam $\mathrm{Pb}$ pada stasiun ini cenderung lebih sedikit ataupun lebih rendah.

Logam berat yang mengendap pada dasar perairan akan membentuk sedimentasi dan hal ini akan menyebabkan biota laut yang mencari makan di dasar perairan seperti udang, kerang dan kepiting akan memiliki peluang yang sangat besar untuk terkontaminasi logam berat tersebut. Jika biota laut yang telah terkontaminasi logam berat tersebut dikonsumsi dalam jangka waktu tertentu dapat menjadi bahan racun yang akan meracuni tubuh makhluk hidup (Palar, 2008).
Sumber alami logam berat timbal secara sedimentasi lewat pengangkutan oleh aliran air dan gelombang. Sedimentasi dapat terjadi di darat atau di laut. Batuan lebih dulu mengalami pelapukan, bahan lapukan diangkut oleh aliran limpas masuk ke sungai. Selanjutnya diangkut ke hilir dan sibir (fragment) batuan yang mengandung logam berat akan mengendap lebih dulu di sebelah hulu daripada yang tidak mengandung logam berat karena berat jenis lebih tinggi (Arsentina, 2013).

Kandungan logam berat $\mathrm{Pb}$ pada sedimen belum melewati ambang batas baku munurut IACDC/CEDA (1997), tentang baku mutu timbal pada sedimen yaitu $83 \mathrm{mg} / \mathrm{l}$, namun kandungan logam berat $\mathrm{Pb}$ pada sedimen tersebut berada dibawah ambang batas atau masih dapat ditoleransi.

Kandungan logam berat dalam bivalvia dipengaruhi oleh kandungan logam berat dalam air, sedimen, dan sifat organisme, serta lamanya pemaparan terhadap logam berat. Bivalvia dipilih dan dianalisis kandungan logam beratnya karena diperkirakan biota laut Bivalvia dapat mentoleransi konsentrasi logam yang tinggi, risiko terpapar bahan pencemar lebih lama, dan dapat mengakumulasi berbagai jenis logam berat yang ada diperairan dan sedimen.

Tabel 5. Kandungan $\mathrm{Pb}$ pada Kerang dan baku mutu timbal untuk Biota (Kepmen LH. No 51 Tahun 2004)

\begin{tabular}{|c|c|c|c|c|c|}
\hline Stasiun & $\begin{array}{l}\text { Kandungan Pb } \\
\text { pada kerang } \\
(\mathrm{mg} / \mathrm{kg})\end{array}$ & $\begin{array}{c}\text { Baku Mutu } \\
\text { Biota Perairan } \\
\text { (mg/kg) }\end{array}$ & Status & $\begin{array}{c}\text { Baku Mutu } \\
\text { Makanan } \\
\text { (mg/kg) }\end{array}$ & Status \\
\hline$I_{\text {sedimen }}$ & 1.48 & 0.008 & $\begin{array}{c}\text { Melebihi } \\
\text { baku } \\
\text { mutu }\end{array}$ & 1.5 & $\begin{array}{l}\text { Melebihi baku } \\
\text { mutu }\end{array}$ \\
\hline$I_{\text {sedimen }}$ & 2.26 & 0.008 & $\begin{array}{c}\text { Melebihi } \\
\text { baku } \\
\text { mutu }\end{array}$ & 1.5 & $\begin{array}{l}\text { Melebihi baku } \\
\text { mutu }\end{array}$ \\
\hline II mangrove & 1.14 & 0.008 & $\begin{array}{c}\text { Melebihi } \\
\text { baku } \\
\text { mutu }\end{array}$ & 1.5 & $\begin{array}{l}\text { Melebihi baku } \\
\text { mutu }\end{array}$ \\
\hline II mangrove & 2.65 & 0.008 & $\begin{array}{l}\text { Melebihi } \\
\text { baku } \\
\text { mutu }\end{array}$ & 1.5 & $\begin{array}{l}\text { Melebihi baku } \\
\text { mutu }\end{array}$ \\
\hline
\end{tabular}

Keterangan: Kepmen LH No 51 Tahun 2004 dan BPOM. 
Berdasarkan hasil pengukuran kadar logam berat Timbal $(\mathrm{Pb})$ pada pada kerang (Polymesoda erosa) di Perairan Koeono menunjukkan bahwa dari tiap Stasiun memiliki kadar logam berat yang berbeda. Hasil pengukuran menunjukan bahwa kisaran tertinggi berada pada Stasiun I yaitu 1.48 $2.26 \mathrm{mg} / \mathrm{kg}$ dan Stasiun II $1.14-2.65 \mathrm{mg} / \mathrm{kg}$. Hasil pengukuran pengukuran lapangan dan dibandingkan dengan Baku Mutu Timbal untuk biota laut berdasarkan Kempen LH no. 51 Tahun 2004 (Tabel 5).

Kadar logam berat $\mathrm{Pb}$ tertinggi ditemukan pada Stasiun I (1.48-2.26 mg/kl) Penyebab tingginya konsentrasi $\mathrm{Pb}$ dalam kerang pada musim penghujan diduga disebabkan oleh tingginya laju erosi pada permukaan tanah yang terbawa ke dalam badan sungai. Partikel organik dan anorganik dari hasil erosi tanah di daratan ini mengandung $\mathrm{Pb}$ dari limbah domestik, sisa pembakaran limbah domestik (misalnya baterai, kertas mengkilap, kaleng) dan dari sedimentasi partikulat $\mathrm{Pb}$ sisa hasil pembakaran mesin berbahan bakar bensin. Pada Stasiun II nilai kadar logam berat pada Stasiun I tidak jauh berbeda karena tingginya kadar logam berat timbal $(\mathrm{Pb})$ pada kerang disebabkan oleh proses pencampuran massa air sungai dan laut yang akan mempengaruhi konsentrasi logam berat terlarut. Hal ini juga disebabkan oleh proses pengenceran dan destabilisasi partikel yang kemudian diikuti dengan pengendapan ke sedimen. Selain dipengaruhi oleh masukan air tawar dan air laut, sedimen pada dasar perairan juga sangat berperan penting dalam perubahan fase logam berat dari terlarut menjadi partikulat. Sebelum terjadi proses destabilisasi, partikel-partikel tersebut mengadsorpsi elemen atau senyawa kimia anorganik terlarut termasuk logam dan organik terlarut dan akan terdeposisi menuju sedimen. Pernyataan ini sejalan dengan penelitian Hamzah dan Saputro (2013) tentang pola sebaran logam berat dan nutrien pada musim kemarau di Estuari Perancak, Bali.

Selain itu perbedaan kandungan logam $\mathrm{Pb}$ disebabkan oleh pengaruh perbedaan substrat atau habitat kerang tersebut telah dibuktikan bahwa logam berat secara alami terdapat pada sedimen yang dibawa oleh aliran sungai, erosi atau jatuhan dari udara, sehingga habitat yang mengandung logam dengan konsentrasi yang berbeda akan berpengaruh juga pada kerang yang hidup di habitat tersebut. Selain perbedaan susbstrat, perbedaan kandungan logam berat pada kerang juga dapat disebabkan oleh perbedaan umur kerang dimana semakin tua umur kerang tersebut maka kecenderungan akumulasi dan peningkatan kandungan logam berat mengalami pertambahan (Riget et al. 1996; Jalaluddin dan Ambeng, 2005).

Logam berat $\mathrm{Pb}$ mempunyai sifat yang mudah mengikat bahan organik dan mengendap di dasar perairan dan bersatu dengan sedimen sehingga kadar logam berat dalam sedimen lebih tinggi dibandingkan dalam air. Logam berat memiliki sifat yang mudah mengikat dan mengendap di dasar perairan dan bersatu dengan sedimen. Hal ini dapat mengindikasikan bahwa seiring dengan berjalannya waktu maka logam $\mathrm{Pb}$ ini juga akan terakumulasi di dalam tubuh biota (kerang) yang hidup dan mencari makan di dalamnya (Amriani dan Hendrarto, 2011).

Berbeda dengan penelitian Afdalia (2017), di Perairan Biringkassi Kabupaten Pangkep menunjukan bahwa kadar $\mathrm{Pb}$ pada ke rrang 3,76-4,23 mg/l telah melebihi baku mutu SNI yaitu $1,5 \mathrm{mg} / \mathrm{l}$ dan menurut Badan Pengawasan Obat dan Makanan Republik Indonesia (BPOM) yaitu $1,5 \mathrm{mg} / \mathrm{l}$. Sedangkan Hasil penelitian Juniarti (2011), di Perairan Pesisir Pantai Makassar diperoleh nilai $\mathrm{Pb}$ pada kerang berkisar 12,94 - 22,81 mg/l. Menurut Darmono (1995), suatu perairan dikatakan memiliki tingkat polusi berat jika kandungan pengambilan timbal oleh organisme air lebih cepat dibandingkan dengan proses eksresi. Tingginya kandungan logam berat pada kerang dibandingkan organisme lainnya karena kerang hewan filter feeder sehingga dapat mengakumulasi logam berat dalam tubuhnya.

Logam $\mathrm{Pb}$ merupakan logam yang keberadaannya dalam tubuh makhluk hidup dapat dikatakan tidak diharapkan. Keberadaan logam $\mathrm{Pb}$ dalam tubuh bersifat menghambat kerja enzim (Purnomo dan Muchyiddin, 2007). Logam berat timbal yang dapat mempengaruhi sistem saraf dan perkembangan otak pada anak-anak selain itu apabila logam timbal sangat tinggi kerang dapat menyebabkan disfungsi ginjal dan kerusakan otak (Suhaimi dan Wong, 2005) Selain itu apabila kadar timbalyang dikonsumsi sangat tinggi maka dapat merusak otak dan ginjal dan akhirnya menyebabkan kematian. selain itu untuk wanita hamil dapat menyebabkan ke guguran (Martin dan Griswold, 2009). 
Kandungan logam berat $\mathrm{Pb}$ pada kerang sudah melewati ambang batas baku munurut Kepmen LH No 51 tahun 2004 tentang baku mutu timbal pada biota perairan yaitu $0.008 \mathrm{mg} / \mathrm{l}$, namun kandungan logam berat $\mathrm{Pb}$ pada kerang sudah terakumulasi dalam daging kerang tersebut berada di bawah ambang batas telah ditetapkan oleh peraturan Kepala Badan Pengawas obat dan Makanan (BPOM) Republik Indonesia Nomor hk. 00.06.1.52.4011 tentang Penetapan Batas Maksimum Cemaran Mikroba dan Kimia Dalam Makanan dan Menurut Standar Nasional Indonesia (SNI 7387:2009) tentang batas maksimum cemaran logam berat dalam pangan, untuk cemaran logam berat pada timbal pada jenis kekerangan (Bivalvia) batas maksimum yang diperbolehkan adalah timbal $1.5 \mathrm{mg} / \mathrm{kg}$ hasil analisisnya sudah melewati ambang batas yang telah ditetapkan, artinya kerang Polymesoda erosa tidak layak untuk dikonsumsi oleh masyarakat.

Dari hasil penelitian ini diketahui bahwa di Perairan Koeono kandungan logam berat $\mathrm{Pb}$ telah terdeteksi ditemukan baik pada sedimen masih berada di bawah baku mutu yang telah ditetapkan, namun pada kerang sudah melewati baku mutu yang telah ditetapkan. hal tersebut tetap berpotensi menimbulkan pencemaran terhadap kerang mengingat kemampuan dan sifat dari kerang tersebut mengakumulasi logam berat $\mathrm{Pb}$.

\section{Simpulan}

Konsentrasi logam berat Timbal $(\mathrm{Pb})$ pada sedimen berdasarkan hasil penelitian yaitu dengan kisaran $0.145-0.345 \mathrm{mg} / \mathrm{l}$ belum melewati ambang batas. Kandungan logam berat pada kerang (Polymesoda erosa) yaitu dengan kisaran $1.14-2.65 \mathrm{mg} / \mathrm{kg}$ dinyatakan telah melewati ambang batas (Kepmen LH No. 51 Tahun 2004) dan sudah melewati baku mutu untuk makanan atau sudah tidak layak dikonsumsi oleh masyarakat (BPOM).

\section{Ucapan Terima Kasih}

Penulis mengucapkan banyak terimah kasih kepada pembimbing dan penguji telah memberikan saran dan bimbingan serta teman-teman yang telah membantu baik dalam pengambilan dan sampai penyusunan skripsi sehingga dapat terlaksana dengan baik.

\section{Daftar Pustaka}

Amin, B. 2011. Distribusi Spasial Logam Pb dan $\mathrm{Cu}$ pada Sedimen dan Air Laut Permukaan di Perairan Tanjung Buton Kabupaten Siak Provinsi Riau. Jurnal Teknobiologi. Vol. 2(1) : 1-8.

Amriani dan Hendrarto. 2011. Bioakumulasi Logam Berat Timbal $(\mathrm{Pb})$ dan Seng $(\mathrm{Zn})$ pada Kerang Darah (Anadara granosa L.) dan Kerang Bakau (Polymesoda Bengalensis L.) di Perairan Teluk Kendari. Jurnal ilmu Lingkungan. 9(2) : 45-50.

Antelo, J., Arce F., Avena M., Fiol S., Lopez R., dan Macias F. 2014. Adsorption of A Soil Humic Acid At The Surface of Goethite and Its Competitive Interaction Withphosphate. Geoderma, Vol.(2) : 12-19.

Armis, A., Hatta, M., P., dan Sumakin A. 2017. Analisis Salinitas Air pada Down Stream dan Middle Stream Sungai Pampang Makassar. Skripsi. Hal: 2-10.

Arsentina, P. 2013. Logam Berat Pb (Timbal) pada Jeroan Sapi, Prosiding PPI Standardisasi.

Bahtiar. 2005. Kajian Populasi Pokea (Bastissa violacea var. Celebensis, vo Martens, 1897), 1897 di Sungai Pohara Kendari Sulawesi Tenggra. Tessis. IPB.

BPOM. 2009. Keputusan Dirjen POM NO. hk.00.06.1.52.4011 SNI 7387:2009 Tentang Batas Maksimum Cemaran Logam Berat dalam Pangan, untuk Cemaran Logam Berat pada Timbal Pada Jenis Kekerangan (Bivalvia)

Darmono. 1995. Logam dalam Sistem Biologi Makhluk Hidup. Penerbit Universitas Indonesia, UI-Press. Jakarta.

Deri, 2012. Kadar Logam Berat Timbal $(\mathrm{Pb})$ pada Akar Mangrove (Avicena marina) di Perairan Teluk Kendari. Jurnal Mina Laut Indonesia, 1(1) : 38-48. Jurusan Perikanan. Fakultas Perikanan dan Ilmu Kelautan. Universitas Halu Oleo.

Effendi, H. 2003. Telah Kualitas Air bagi Pengelolaan Sumberdaya dan Lingkungan Pencemaran Penerbit Kanisisus. Yogyakarta. 252 hal.

Erlangga, 2007. Efek Pencemaran Perairan Sungai Kampar di Propinsi Riau Terhadap Ikan Baung (Hemobagrus hemurus). Tesis. Sekolah Pascasarjana IPB Bogor. 87 hal 
Heru, S. 2013. Akumulasi dan Distribusi Logam Berat pada Vegetasi Mangrove di Perairan Pesisir Sulawesi Selatan. Jurnal Ilmu Kehutanan Vol. 7(1) : 1224.

Jalaluddin, M. N., Ambeng. 2005. Analisis Logam Berat $(\mathrm{Pb}, \mathrm{Cd}$ dan $\mathrm{Cr})$. Universitas Hasanudin. Vol. 6(2) : 1720.

Juniarti Pratiwi S. M. 2011. Analisis Logam $\mathrm{Pb}$ dalam Kerang Hijau (Perna viridis L.). di Pesisir Pantai Makassar.

Martin, S., Griswold, W. 2009. Human health effect of heavy metals. Kansas State University. Vol. 2(3) : 4-5.

Nyabakken, J. W. 1992. Biologi Laut Suatu Pendekatan Ekologi (Terjemahan). Gramedia. Jakarta. Hal : 213.

Odum, E. P. 1996. Dasar-Dasar Ekologi (Terjemahan). Gajah Mada University. Yogyakarta. Hal : 625.

Palar, H. 2004. Pencemaran dan Toksikologi Logam Berat. Penerbit Rieneka Cipta. Jakarta. Hal : 289.

Palar, H. 1994. Pencemaran dan Toksikologi Logam Berat. Jakarta: PT. Rhineka Cipta.

Purnomo, T., \& Muchyiddin. (2007). Analisis kandungan timbal $(\mathrm{Pb})$ pada ikan bandeng (Chanos chanos Forsk.) di Tambak kecamatan Gresik. Jurnal Jurusan Biologi FMIPA. Vol 14(1) : 68-77.

Rochyatun, E dan Rozak, A. 2007. Pemantauan Kadar Logam Berat dalam Sedimen di Perairan Teluk Jakarta. Makara Sains, Vol. 11(1) : 28-36.

Sahara, E. 2009. Distribusi $\mathrm{Pb}$ dan $\mathrm{Cu}$ Pada Berbagai Ukuran Partikel Sedimen di Pelabuhan Benoa. Jurnal Kimia. Vol. 3(2) : $75-80$.

Suhaimi, F., Wong, S. P. (2005). Heavy metals in fish and shellfish found in local wet markets. Singapore. Journal of Primary Industries. Vol. 32(4), 1-8. 